\title{
Reflections on Liability and Full Reimbursement of "Restituito in Integrum" Damage in Insurance
}

\author{
Dr. Juliana Bylykbashi \\ Asoc. Prof. Dr. Eneida Sema (Dervishi)
}

Faculty of Justice, University of Tirana, Tirana, Albania

Doi: 10.36941/ajis-2019-0052

\begin{abstract}
The institute of civil liability in most of the legal systems is mainly oriented towards compensation of damages, which is the main objective. The feature of civil liability is to restore, as precisely as possible, the impaired balance and restore the injured party to the state he would be, if it had not been for the act that harmed him. The existence of civil legal liability for damage caused is an important segment in the context of ensuring a higher level of protection of human rights, legally protected. The state must guarantee not only the constitutional rights of the individual, but also the right to be rewarded, in case anyone trespasses or violates them, guilty or not. Being a constitutional right (Article 44 of the Constitution of the Republic of Albania) rehabilitation or indemnification in accordance with the law, Restituito in integrum aims to restore the former condition of the injured party, as far as possible, through rehabilitation and, if this is not possible, convert this condition into monetary and indemnity. If we refer to the Albanian case law, there have been many cases in the insurance field that have been controversial by the courts of some levels, which relate precisely to the elements of civil liability and damages. This study will focus on and analyze some litigation related to the application of the terms of civil liability and damages, in terms of non-contractual damages. In view of the problems encountered in law enforcement in practice, the question rightly posed is whether: in Albanian case law has it been possible to have a "restituito in integrum" and satisfy the injured party or parties?
\end{abstract}

Keywords: material reward, non-pecuniary damage, the causal link, fault, civil liability

\section{Introduction}

The path for compensation of damages is wide, but through the treatment of this paper we will mention some aspects related to certain conditions of civil liability and consequently compensation of damages, mainly in the field of compulsory insurance, in compensation of extra-contractual damages, in damages suffered by the third parties. One of the key virtues of the full reimbursement rule is to enable, and even encourage, a continued re-discussion of the indemnity-missing profit (interests) valuation methods to adapt them promptly and concretely with individual situations and new opportunities, to relieve the injured persons resulting from the evolution of science, technique and social conditions. The jurisprudence of the European Court is rich in the content and implementation of the "fair remuneration" applicable in the event of inability to be realized at national level "restituito in integrum". This right applies where the indemnification in the narrow sense is impossible and is solely aimed at compensation or mitigation of damages incurred. (Viney G, Jourdain $P, 1989$ ).

Once a claim for damages has been initiated, the judge, as soon as he finds the existence of 
the conditions of civil liability, must assess the damage and the interests. For this he often stands on the essential principle that dominates the field, namely: total damage compensation or the matching between damage and compensation.

This rule is accepted by most legal systems. Based on this principle the courts have derived two types of consequences: they consistently recognize that the damage assessment must take into account all the constituent elements of the damages whose repair is claimed by the injured party, provided that such damage have been caused by a fact of damage and that indemnity must be such as to fully and efficiently compensate such caused damage. But they also specify that indemnity should not exceed the value of the damage and not allow any enrichment of the injured person. In other words, the amount of indemnity and interest must coincide exactly with the loss caused by the fact of impairment.

This paper will deal with several issues such as: the lack of one of the essential elements of causing harm, will the injured party be entitled to claim compensation from the insurance company? Is it necessary to divide liability in the event of a car accident for a right and complete reimbursement to the injured party? In the practice of insurance companies we have encountered the fact of signing a statement or transaction that is made to indemnify the injured. Does this practice violate the principle of "Restituito in integrum"? The treatment of these cases will go through the analysis of some court cases.

\section{The Value of the Principle of Full Compensation}

The right to redress is a right protected by Additional Protocol Nr. 1 of the European Convention on Human Rights. The Strasbourg Court has ruled that a total lack of indemnity for a secure claim would be justified only in exceptional circumstances. A study on "damages in the light of the European Convention on Human Rights" has shown that this Convention has not provided at all for a general right to redress and that its jurisprudence results, on the contrary, that it interdicts the recognition of a right of redress by finding a violation of one of the fundamental rights contained in the Convention. (Marchadier, F 2009)

The principle of "Restituito in integrum" has a number of advantages that are uncontested and of great importance. It enables the injured to receive an effective compensation for the damages suffered by third parties. What constitutes the advantage of this rule, in this respect, in relation to the methods of indemnity with limited limitations (Section 26 of the Compulsory Insurance Act $10076 / 2009$ ) or set forth in formulas (or tables), is not the mere fact that it provides a more complete reparation: even if this rule is more easily applicable and convenient. First easier with the technical progress and modifications of social indemnification data. For health damages, for example, the principle of full reimbursement allows for the inclusion of liability for the treatment and medical care that authorizes medical science and techniques, although more modern methods are far more costly than previously practiced. Likewise, it can be concluded that the principle of complete compensation induces judges to arrange it with particular situations that could not be considered by the more mathematical and rigorous formulas. For example, in a decision the Supreme Court of Paris (Judgment of 6 July 1983) ruled that for the compensation of health damage suffered by a person with a disability, it was more appropriate to abandon the classic proportional compensation formula by the percentage of disability and be replaced by a completely different method. The Court has held that... "The special situation of a person with a disability requires specific compensation for the post-trial period". It is necessary to replace the usual compensation system with a method tailored to real needs in the future, of the person with a disability, to provide him with the conditions for his survival and as satisfactory as possible, taking into account the environment where he lives. It is clear that without the principle of "complete reparation" such an adaptation, which is more than human and socially fulfilled, would not have been accomplished by a judge.

Nowadays, civil liability is not limited to protecting individuals and groups from harming their property. In many places it aims to protect them from a range of non-property damages, such as "pain and suffering", damage to their reputation, personality and even feelings and compassion. This expansion of the definition has forced jurors to go beyond the optics of indemnification for non- 
pecuniary damage. If we take as an example the Kosovo legal system how they apply the principle of full compensation has evolved, adding to the variety of damages awarded. Given the principle that compensation should be as fair as possible, the importance of the transgressed good, the purpose that this compensation serves, and the fact that the compensation does not fit the goals that are inconsistent with its nature and social purpose, in addition to compensating for spiritual pain due to reduced general life activities, the bodily injury that the victim has experienced, that he is currently experiencing and will experience in the future, in reducing some of the pleasures and joys that he has been deprived of due to injuries sustained, compensation for the fear experienced. (C.nr.415 / 10 dated 18.09.2013 Judgment of the Basic Court Prishtina). Compensation for the consequences of fear on the injured person is determined by the intensity and duration of the fear (Judgment Basic Court Prishtina C.nr.199 / 11, 04.12.2014), dividing it into two forms; a) primary fear, which is the intense feeling of short duration (a few seconds) demonstrated, perceived and experienced by the person injured at the time of the accident and b) secondary fear is the feeling experienced by the person injured by the traffic accident and after the accident, injuries received and related to the course of treatment, as well as the potential consequences.

In assessing damage compensation, although most EU countries allow for full compensation of past, actual and future losses "restituito in integrum" including property and non-pecuniary damage, in practice the level of damages awarded and the limit of compensation can vary considerably from place to place. Based on both liability and insurance regimes, countries have adopted different calculation criteria.

In the US there is the principle of "Eggshell skull" (Mataj, R 2017) or the eggshell crack, in tort law operating in Commonwealth countries such as the UK, US, Australia, etc. This principle implies that whatever kind of damage is caused to the injured person, even though it is as delicate by nature as the eggshell, the respondent is obliged to compensate for all the damages incurred despite the fact that other factors belonging to the injured party have contributed to the damage.

\section{Legal Analysis of Albanian Case Law on Liability and Compensation for Insurance Damage}

If we refer to the Albanian legal system, we find that the prevailing theory of damages is the same as that of default, where the debtor intends to fulfill the obligation in nature and if this is not possible, in money. Monetary remuneration is a subsidiary of the in-kind compensation of pecuniary damage. This means paying a sum of money to balance a claim that cannot be remedied directly.

The Albanian legal framework is based on the institute of civil liability known as aquiline responsibility (lex Aquilia de damno) which states that: ... "anyone who violates the legitimate rights and interests of another shall be obliged to indemnify him", as one of the fundamental principles of coexistence in human society, the prohibition to harm one another (alterum non laedere or neminem laedere). Its implementation is generally regulated in the Civil Code and in particular in the provisions on tort civil liability provided for in Article 608 et seq., which stipulates that: "A person who unlawfully and blamably causes harm to another person and his property shall be obliged to pay damages."The following are known as non-property damages: moral, existential and biological damage, but also any other damage that infringes rights, values or freedoms recognized by law or good practice.

In Albania, the identification of the types of damage that the injured person and his or her relatives (indirect victims) may suffer and the ways and means of their compensation were significantly consolidated in practice following the unifying decision of the United Colleges of the Supreme Court no. $12 / 2007$. Mostly it is non-property damage as the property damage is clear from the concrete provision of the Civil Code itself for both contractual damages (Article 486 of the Civil Code) and non-contractual damages (Article 640 of the Civil Code).

In the case of compulsory insurance including those to cover the liability of motor vehicle drivers to the thirds, the relationship between the insurance company and the insured is an insurance contractual relationship, which has a special arrangement by Lex Specialis in the compulsory insurance. Whereas in matters relating to compensation of damages, the provisions of the special legislation on compulsory insurance and the provisions of the Civil Code on extra- 
contractual liability apply. (Articles 608 et seq.). The relationship between the insurance company and the insured on the one hand, and the injured on the other hand is a relationship of a noncontractual nature. In the case law, there have been few cases where the legal relationship between the insurance company, the insured and the injured party has been confused. This has also led to the confusion of the correct application of the full reimbursement of damages as well as the incorrect calculation of the prescription period within which the injured party should file a claim for damages.

Regarding the non-contractual damages compensation cases, the Joint Colleges of the Supreme Court, by decision no.12, dated 14.09.2007, have unified the judicial practice for the application of Articles 608,609, 625, 643/a and the following of the Civil Code. In this decision, the Joint Colleges have expressed in substance about the entities having the subjective right (active legitimacy) to seek compensation for the property and non-property damage suffered, the figure of biological or health damage (as a special figure of non-property damage), the figure of moral and existential damage, methodology of calculating the amount of compensation etc.

In order for the concept of compensation to exist, the damage must have been caused by guilt as a result of an unlawful act and this harm is directed to the property or human interests of the citizens. In order to accept civil liability there must be cumulatively four legal elements that must compete together which are: the existence of the damage, the illegality of the action or omission, the fault and the causal link between the action/omission and the resulting damage. The cumulative nature of the conditions governing non-contractual liability means that, if one of them is not fulfilled, the claim for damages must be dismissed in its entirety and there is no need to consider the other conditions.

If we refer to the Albanian case law in the field of insurance there have been many cases that have been controversial by the courts of several levels that relate precisely to these elements of civil liability and damages. The question rightly arises: if one of the essential elements of causing damage is missing, which is precisely the fault in causing it, is the injured party legitimated to seek compensation from the insurance company?

To answer this question we will need to analyze some court cases. In the Judicial Case (Decision No. 173, dated 31.03.2015 of the Civil College of the High Court).......M. as a passenger in the vehicle driven by N.P. suffered extensive bodily injury as a result of the accident. Due to his health condition, he was found by KMCAP (Article 80 of Law No. 7703/1993 on social security) as incapable of working fully and being categorized in the second group of disability. The accident was the result of a fault in the steering system, tire breakage and bad weather conditions. As a result of the judicial inquiry it turned out that N.P. the driver had no responsibility for his fault.

The Supreme Court in another similar case (Decision No. 174, dated 05.03.2013 of the Supreme Court) states:... While the trial proves that the victim F. A. had no liability whatsoever for the accident. The court of appeals confuses civil liability with the criminal one. Especially in the case of compulsory motor insurance where, the insurance company is not entitled to object to the injured person with respect to the right to compensation.

The object of securing civil liability is not the means (loss or damage of them), but the damages suffered by third parties, from the exercise of their profession and activity by entities that have undertaken to exercise them or which the law has imposed upon them as an obligation to exercise. If there are no grounds for exemption from insurance coverage under the law and the terms of the contract, the insurance company shall be liable for damages caused to third parties by the entities exercising the insured activity with that insurance company.

There is a consolidated case law that recognizes liability for damages caused to third parties even where it is established that the driver is not guilty of causing the accident. However, unlike criminal liability, where e.g. guilt is an indispensable element of criminal liability (Article 13 Criminal Code), in the case of civil liability, there is also illegal behavior or not, which, even if committed without fault, again bring civil liability.

Even the case law of the Supreme Court has reflected this fair interpretation of the law as regards civil liability from the practice of dangerous activity. In this case the insured's liability for the hazardous activity he carries, and not merely the personal liability of the insured who exercises or delegates the driving of the motor vehicle is assured. For this very reason, these persons cannot be 
the injured third party and cannot seek and obtain damages. (Article 23, a) b) of Law 10076/2009 on compulsory insurance).

Therefore, it is crucial to determine whether there is an insurance case, whether the insurance company should indemnify or not the injured party, to establish the causal link between the activity of the motor vehicle and from motor vehicle and property and non-property damage that anyone has suffered because of this activity.

Thus, as in other legal systems, the Albanian Civil Code, in some of its provisions, provides for the regulation of the legal institute on non-guilty civil liability (otherwise called objective or presumed guilt). The Civil College seeks to identify civil liability arising out of the conduct of a dangerous activity under section 622 of this Code: shall be obliged to pay damages, unless it proves to have taken all appropriate and necessary measures to remedy the damage. "So if a dangerous activity is exercised (source of increased risk) the one who exercises that activity is obliged to indemnify anyone who has suffered damage due to the exercise of that activity. In this case the "danger" lies not with the one who exercises it, but with the very nature of the activity or the objects used. It is a liability that comes based on modern risk theory (Mataj, R 2017) so persons who benefit and bring risks to third parties or use items that are potentially dangerous to the life, health and property of the third party will necessarily retain responsibility for them.

This position was also held by the Civil College of the High Court which in decision no. $70 / 2010$ states that:... "It does not matter, in terms of law enforcement, whether the actions or omissions of the respondent are unlawful or whether they have been committed by him. It does not matter, in terms of law enforcement, whether the defendant has been ordered not to institute criminal proceedings in connection with the event. It doesn't matter, in terms of law enforcement, if the weather was bad, if the motorcycle breakdown was unexpected and other circumstances where the courts of fact are based. These circumstances are not those which, by law, exclude a person who carries out hazardous activities from liability for damage caused. "Similarly, the Civil College of the High Court, in decision no. 73, dated 16.02.2010 in particular for the interpretation of Article 622 of the Civil Code it is stated that: ...... also the activity of water transport of passengers and vehicles... .. constitutes a source of increased risk within the meaning of the Civil Code and the Maritime Code, in its Article 7. In the exercise of these activities the liability of the cause of the damage is not subjective, thus linked to guilt in his actions, but it is the responsibility of an objective nature.

The European Court of Human Rights has gone further in its interpretation, finding that (Case No. 57/1996/676/866 dated 25 September 1997) any unlawful act which could constitute a crime or extra-contractual harm, who inflicts moral or property damage legitimizes the injured party to bring a claim for compensation in civil courts against the offender despite the guilt: willful, negligent, excessive self-esteem, etc.

\section{4. $\quad$ Mixed Responsibility}

There are numerous cases where as a result of the occurrence of an insurance event (car accident), the cause of its occurrence is the actions or failures of fault of both drivers involved when there is practically the most frequent case where two vehicles collide, or when we have collisions of more than two vehicles, but each driver has a breach or contribution to cause the accident or increase the consequences. These acts specify the violations of each accident participant and then determine the determinant cause, which has been the cause of the accident, and the responsible offender, who subsequently bears criminal or administrative liability and is automatically excluded as the beneficiary of insurance because of his guilt.

In civil trials, where such cases exist and an autotechnical expert is called upon to determine the dynamics of the event, the tasks often left by the Court at the request of the respondent parties (insurance companies) require that the expert make a division or report the guilt of each driver expressed as a percentage of the extent of the accident contribution. The case law recognizes several cases, although not numerous, in which percentage liability has been split and the claimant beneficiary at trial has been deducted from the amount of his or her guilt expressed as a percentage, a deduction made to the full value of damage. The expert in the act of auto-technical 
expertise has concluded for complicity in the event, in reports 50 to 50 , the driver and the passenger stating:... I find that the determinant cause are the violations committed by both road users involved in the accident and from a quantitative perspective, the violations have had an impact on the conduct of this road accident, equally 50 by 50 . The question that arises in this case is: Will they both be liable and consequently co-indemnifier to third party for the damage he has suffered to health? Will the passenger of the vehicle, which in the second act of expertise has been the cause of the determinations for the consequence, health damage to the third party, be guilty and consequently jointly liable?

In Albanian criminal law, some actions or persons may compete in the consequences and here the problem is compounded. Each person shall be held liable in such cases for the result which has been the necessary consequence of his act or omission. The notion of the vehicle being involved in an accident makes it possible for a driver to be held responsible even though he had no causal role in the occurrence of the injury, (Quézel-Ambrunaz Ch, 2010).

When persons have done joint actions and the consequence has been the result of these joint actions, then the role and significance of the actions of each of them is analyzed. This is done not only when actions are done intentionally, but also by carelessness. (Hoxha D, Kacupi S, Haxhia M, 2018). Whereas in the determination of civil liability and in consequence of the indemnity, the Courts have held that in view of the injured party's guilt report, the extent of the benefit in compensating the injured party must be calculated. Blame escalation is an element considered by the court to increase or decrease the pest's liability compared to other co-defendants or towards the injured party.

In another civil case, the Court stated (Decision No. 1776 of 12 July 2017 of the Court of Appeal, Tirana)... .. "the passenger's behavior is a complementary part of the driver's conduct in relation to the third party. Thus, the responsibility of the vehicle driver is inclusive in the sense that it includes everything that is directed and controlled by it in the driving of the vehicle, which necessarily carries with it the behavior of each individual (passenger) as an integral part of his responsibility. It is precisely the driver of the vehicle, the cause of the accident, who in relation to the third party must be held responsible for the conduct of any physical action related to his vehicle, no matter who does it. The liability for the passenger behavior of a vehicle in the event of an accident may not be shared between the driver and the passenger for the latter's personal conduct in relation to a third party. In this case the cause of the accident was the driver of the vehicle, insured with the insurance company and under these conditions the company has the obligation to pay health insurance to the injured party.

Concerning the culpability implicated in an accident where the cause of the accident was the two motor vehicle drivers' violations and that the ratio between these violations which affected the accident was $70 \%$ to $30 \%$, what will be the amount of property and non-property indemnity against the injured with permanent disability in the amount of $35 \%$ ? The court concludes that the injured party's compensation should be calculated from the injured party's compensation report. The amount of the benefit to the injured party will be reduced in proportion to the extent that it itself has affected the damage at $30 \%$, and the amount of damage it will benefit will be reduced by $35 \%$, as calculated by the evaluation expert (Decision No. 4254 dated 11.05.2018 of the Tirana Judicial District Court and decision no. 236 dated 06.03.2019 of the Tirana Court of Appeal.)

\section{Causal Link}

One of the important elements of guilt determination is the causal mechanism. The causal connection may not always be easily and clearly established. Thus, in certain cases, the judge presents complicated situations where it is very difficult to ascertain this link between the harmful act and the consequence. Confirmation of causal link is necessary in all cases, whether in personal responsibility, responsibility for others or liability for dangerous objects and dangerous activities. In the case law, it is preferable that in these cases the judge in examining and deciding the case for the award of damages in order to determine the causal link correctly it must be accompanied by experts in certain fields to make the right decision. Confirmation of the causal link is an essential condition, respectively, for the admission of the criminal and civil liability of the perpetrator of the 
unlawful fact, as well as for the determination of the criminal conviction and the corresponding civil obligation. For the acceptance of civil liability as a consequence of extra-contractual damage, the material causal link and the legal causal link between them must be established (Unifying Decision No. 12 of the United Colleges of the Supreme Court).

If we refer to another case from practice, with regard to the cause-effect element, how would we reason if we would have been in such a case, when due to an accident on 19.07.2002 the death of a minor child 15 year, mother of the victim, who in depression due to the death of her son was thrown from the bridge and died on 12.10.2002? Will the insurance company know about the insurance case and then reimburse the victim's relatives, where according to the death record it results that death was caused by drowning and cerebral coma? Is her family entitled to claim damages?

"The Civil College of the High Court (Decision No. 199, dated 15.05.2014, Civil College of the High Court) regarding this matter is expressed ......"In the case of the death of the mother it does not appear that the whole set of evidence in relation to the law has been analyzed, no legal argument has been given to support her conclusion that the mother's death is a direct consequence of the unlawful actions of the author of the car accident."

The causal connection is one without which no harm comes to the injured person. So it may be harm, but to link the act or omission to the harm caused must have a direct and determinate link in the consequence or figuratively in the chain linking the unlawful fact and the harm there must be no broken link. (Mataj R, 2017). The main problem that needs to be answered is what is needed to determine that a consequence is the cause of a particular action. The Albanian Criminal Code has not provided any answer regarding the determination of the criteria or conditions that should exist for causal link, leaving all interpretation to the theory and practice followed by the judiciary. In assessing this case it should be kept in mind that causal linkage is not only an objective category but also a process that takes place in time and space (Hoxha D, Kacupi, S Haxhia M, 2018). Although the mother's suicide occurred 2 months after the loss of her son's life, the experience of maternal pain caused by her son's loss, the close relationship that exists in the parent-child relationship, and especially the mother-child relationship, should be analyzed, the affective degree of pain and spiritual suffering that the loss of her child's life has left. The case does not resemble the case, so the degree of pain experienced is individual and unique. The mother's aggravated psychological condition, her immense pain over the loss of her infant son, has resulted in her suicide. A French author (Quézel-Ambrunaz Ch, 2010) argues that... the sequence of causes and effects is not just about material elements, even the psychological state of man may be integrated into the causal chain.

I think that in this case the causal link is not interrupted, but the burden of proof, (onus probandi) which belongs to the injured party, mother's family, it is difficult to prove. It must be proved the aggravated psychological condition of the mother due to the death of the minor child, reports from the psychologist, antidepressant medication if used, in the period following the child's death. If attested by relatives, then surviving members of the 15-year-old and his mother enjoy active legitimacy to seek redress in the quality of the injured, for damage to health and other property and non-property interests suffered, as a consequence of the death of their relative by the unlawful fact of the third.

\section{Limits of Liability Coverage to Injured Persons}

One of the issues to be discussed in this paper is the limit of liability coverage in the event of road accidents. For the first time, compulsory insurance in the field of transport is regulated by Decree no. 295, dated 15.09.1992 "On compulsory insurance of motor vehicle owners for liability to third parties", and subsequently the adoption of Law no. 10076, dated 12.02.2009, "On compulsory insurance in the transport sector", which has provided, inter alia, the limits of liability coverage, ie the maximum amount of reparation that injured persons may benefit (the limit of coverage, respectively by the insurance companies or the Albanian Insurance Bureau for one person, is in the amount of 20,000,000 (twenty million) ALL defined in point 2, letter "b" of Article 26).

The imposition of a liability limit in the case of road accidents is justified by the fulfillment of a 
public interest, protecting the insurance companies' budget and compensation fund to guarantee the functioning of these companies. On the other hand, the creation of such societies constitutes an assurance of the full compensation of persons injured as a result of a road accident.

This provision sets limits on the value of indemnity, but on the other hand, in point 3 of Article 26 , it is sanctioned that when there are some injured parties the value of indemnity can again not exceed the limit of coverage specified in point 2 thereof. including the limit of non-property damage coverage. So either in the case of some injured or logically in the case where an injured person benefits from several persons, including himself, the maximum value of non-pecuniary damage compensation may not exceed the limit of coverage specified in point 2 (b) of section 26 of the Act. No. 10076/2009, "On compulsory insurance in the transport sector".

It is noted that the total amount of compensation per person, from Decree to Law, has remained unchanged at 20,000,000 (twenty million ALL), while the standard of living and overall wage level has changed drastically since 1992 , when the Decree entered into force until 2009, when the latter was replaced by the Law. Keeping the same amount as the coverage limit since 1992 is not justified by new economic circumstances, money buying power, increased standard of welfare, as well as the amount received by insurance companies as a result of payment of insurance premium by all insureds.

In the former situation it is found that, while an injured person in a field other than transport has no limit on the value of the benefit, in the latter, the maximum value of the property and nonproperty indemnity is 20,000,000 (twenty million) ALL. In the second situation there is another limitation, the value of non-pecuniary damage, which cannot be compensated beyond the limits provided for in Article 26, paragraph 2, letter "b" of Law no. 10076/2009. While setting a ceiling value for total indemnity may be justified by protecting the finances of insurance companies, linked to their solvency, ie their ability to indemnify persons injured by an accident, the existence of another barrier, as is the ceiling value for non-pecuniary damage, is unreasonable and not objective.

The issue at stake relates to whether the extent of this indemnity responds to the actual damage sustained by the injured person. If the limitation of the total compensation value can be considered proportional for the given reasons ut supra (protection of finances of insurance companies or of the compensating fund and as a result maintaining their solvency), imposing a double restriction or the limitation on limitation, which relates to the value of non-pecuniary damage compensation, is wholly disproportionate.

The referring court has referred the case to the Constitutional Court (decision no. 13 dated 27.01.2015 Judicial District Court of Fier) to express the constitutionality of Article 26, paragraph 2, letter "b" of Law no. 10076/2009, which violates the principle of legal certainty, as it has worsened the financial position of the compensation beneficiaries of accidents in the transport sector, without a justified and objective reason.

\section{Waiver of Compensation by the Injured Party Infringes the Principle of "Restituito in Integrum"?}

It is often the case in practice that after the indemnification has been effected the injured party agrees with his harmer or insurer to sign a transaction or statement by which the full indemnity is waived. The positions of the courts of various levels, as well as those of the Civil College of the Supreme Court have been different in the interpretation of the proceedings and the legal consequences of the actions performed by the insurer and the injured party in cases where compensation is claimed. The applicable laws and by laws in the field of compulsory insurance provide for the insurer's obligation to provide the injured party with the amount of compensation for the damage caused by the insurance case. In the absence of an adverse written agreement, is the injured party entitled to apply to the Court to seek a different amount of damages and the missing profit if he withdraws the value offered by the insurer? (Decision No. 1 dated 09.01.2008 of the Joint Colleges of the Supreme Court). We are in the situation when the injured party has signed a written statement with the object: Declaration of acceptance of the value of the indemnity, in which he has agreed and accepted the value given by the insurance company in the form of the relevant 
indemnity. After receiving this amount, the injured party claimed the difference between the payment of pecuniary and non-pecuniary damages.

The question arises: Acceptance and withdrawal by the injured party of part of the indemnity offered by the insurance company constitutes a waiver of the right to claim the rest of the indemnity, which belongs to the injured party under the law and in fulfillment of the full compensation of the damage? And the second question that remains to be addressed: is the insurance company's liability to the injured party extinguished by signing the statement?

Regarding to this issue, several courts (decision 714/2012 of Court of Appeal of Durrës and decision no. 2614/2011 Court of Appeal of Tirana) have taken decisions based on the erroneous reasoning that as long as we have a voluntary agreement regarding the payment of damages that is, the parties agree to settle the case out of court regarding the payment of the damages, then the court finds that we are under contract law, where according to the doctrinal concept of this right it is the agreement of the parties or the concurrence of their will to create, alteration or termination of the property legal relationship (Article 659 of the Civil Code). In this case the courts argue that the insurance company as a debtor has fully fulfilled its obligation to the injured party, releasing itself from the debtor's legal status.

If we were to argue about the legal consequences of resolving the questions raised, we would argue that: First, the written declaration of the receipt of the compensation by the injured party is in itself a limitation on the insurer's liability (Article 479 Civil Code) regarding his legal obligation to pay full damages. By legal acts and by laws, it is clearly stipulated that the amount offered for damages in each case must match the amount of damages. Secondly, the fact that the injured party has withdrawn the amount offered by the insurance company does not deprive them of the right to seek, through the statutory limitation period, the actual value of the damage through the court (Article 115 Civil Code). Third, to consider this statement as a waiver of the lawsuit means to prevent the plaintiff from returning to the state it was before non-pecuniary damage occurred (Principle of Restituito in integrum) Acceptance and withdrawal of part of the award by the injured, offered by the insurance company does not constitute a waiver of the right to claim the rest of the compensation due under the law nor the full fulfillment of the obligation by the insurance company (Articles 422 and 455 Civil Code). Fourth, on the basis of the above argument does not stand also point 4 , article 70 of law no. 52/2014 on insurance and reinsurance activity with the object of dispute resolution, which runs counter to the principle of full compensation of damages, restituito in integrum.

As above, we have also answered the second question, by analyzing the provisions in harmony with each other we conclude (decision no. 517 dated 17.12.2015 of the Civil College of the High Court) that: the debtor (the insurance company) has civil liability for default, even in the case of partial default, so the injured party's acceptance of the amount offered by the insurance company does not constitute a termination of the latter's obligation to pay in full of the compensation due to the injured. In the interpretation of Article 479 of the Civil Code ..." any agreement that excludes or restricts the parties from liability for non-performance of obligations is void.

Another controversial issue with regard to full reimbursement is also the missing profit and the interests that should be rewarded. The question is: Does the missing profit apply to the special mandatory insurance provisions (lex specialis) and if the special law sets a statutory limit to this limit will the missing profit also be included?

In some cases the courts have erred in formulating the missing profit by confusing it with the bank interest that the insurance company should repay the injured party because of the delay in paying the indemnity (Decision No. 850, 08.05 .2006 of the Court of First Instance, Vlora) If we make an analysis of the provisions of the Civil Code, Article 450 stipulates that the interest received is simply a default interest which becomes payable, because the delay has already taken place and when the claimed interest is claimed, the interest is ripe to be harvested. (Tutulani M, 2016) In other words, interest earned is a type of compensation (to be precise, the portion of the loss related to retained earnings) derived from non-execution in the due time and manner of cash liabilities.

According to the Civil Code legal provisions, the missing profit (Article 486 of the Civil Code) lucrum cessans is the impossibility of obtaining a future interest in property, that is, an asset not yet owned by the injured party at the time of the damage. The missing profit is included in the concept 
of loss suffered consequently it will be included in the statutory limit of indemnity in compulsory insurance by the insurance company. Whereas the obligation to settle bank interests as a result of the delay in the settlement of a liability, that is, of property or non-property damage suffered in a contractual non - contractual relationship is not included in what constitutes retained earnings under the Civil Code (Decision no. 233, dated 25.05.2010 of the Supreme Court Civil College). Delay in the settlement of the damage (liability) is the responsibility of the insurance company itself, in direct relation to the injured party and has nothing to do with the legal limit of indemnity provided by the compulsory insurance legislation. If the damage suffered exceeds the statutory limit, the injured party has the right to claim the amount above that limit directly only to the person causing the damage.

\section{Conclusions}

The main purpose of the award of damages is for the victim or injured party to return as far as possible to the state in which they were before the unjust act occurred. This explains the reason why most of the victims compensated by insurance companies address to the Courts for the benefit of the rest of the indemnity.

Often because of the complexity of the relationship of obligation, the main problem has been and remains the question of determining responsibility. In case law the issue of ascertaining the responsibility of the responsible entity often remains very complicated either because of the circumstances of the case or because, in some cases more persons are on the side of the responsible entity who must respond on the basis of the principle of solidarity responsibility, or situations where damage can be caused without fault.

Civil liability has no criminal function and the importance of guilt cannot justify a sentence above the value of the damage caused, which would enrich the beneficiary. The same is true for lack of guilt or ease of guilt, which should not be taken into consideration to reduce compensation.

The Albanian Criminal Code has not provided any answer regarding the determination of the criteria or conditions that should exist for causal connection, leaving all interpretation to the theory and practice followed by the judiciary. This situation may create confusion knowing that causality is precisely "the boundary between civil liability and compensation".

Other causes, such as the victim's own guilt, etc. may reduce the amount of damage compensation by the offenders themselves. Recent sentences of the Albanian courts at various levels are also taking into account the degree of guilt or mixed responsibility, an element being dealt with by the court to increase or decrease the liability of the offender vis-à-vis other cooffenders or the injured party.

Accurate determination of the legal position of the person responsible and the injured party in the legal relations that arise with the infliction of damage turns out to be one of the key values to guarantee legal certainty, within the efforts of legislators, judges and doctrines.

The issue of compensation for damages caused by vehicles is a matter of particular importance, since when determining the amount of compensation for damages, insurers present deficiencies and therefore, the injured parties address to the courts. Courts in their decision-making should consider the real valuation variant, which represents the most realistic, fair and objective values of reparation, as these values have correctly aligned the value of the damage, as with market economy principles with social change.

The approach of national legislation as much as possible with that of the European Union countries in terms of both the limits of indemnity and the method of calculation is a challenge to Albanian national legislation with that of the European Union countries, in which the extent of this indemnity responds to the actual damage suffered by the injured person/s.

\section{References}

Hoxha, D, Kacupi S, Haxhia., M, Criminal Law (2018) - General Part, Jozef Editions, 2018, pg.229

Lambert-Faivre Y, ( 1998 ) L'indemnisation des victimes de préjudices non économiques, pg. 540

Lambert-Faivre Y, Leveneur L, (2011) Droit des Assurance, Dalloz, 13 edition, pg. 408 
Marchadier F., (2009) La reparation des dommages a la lumiere dela Convetion europeenne des droits de I homme,RTD, pg.245

Mataj R, Non pecuniary damage and case law 2008-2010, pg.3

Mataj R ,(2017) Tort Law of public entities in Albania, Tirana, 2017, pg.68

Quézel-Ambrunaz Ch, (2010) La Causalite dans le Droit de la Responsabilite Civile Europeenne, Séminaire du GERC, mars 2010, Genève, pg.23

Tutulani, Semini M, ( 2006) "Law of liabilities and contracts" general part, the third edition, Skanderbeg books, Tirana, pg.170

Viney G, Jourdain P,(1989) Les effets de la responsabilite, Traite de droit civile, L.G.D.J., Lextenso editions, pg. 4

Constitution of Republic of Albania, modified by law no. 9675, date 13.1.2007,

Civil Code of Republic of Albania approved by law no. 7850 date 29.07.1994,

Civil Procedure Code of Republic of Albania approved by law no.8116, date 29.3.1996,

Criminal Code of Republic of Albania, approved by law no. 7895, date 27.1.1995, updated in August 2017

Law No.9251, date 8.7.2004., Maritime Code of Republic of Albania.

Law No. 10076 /2009, For compulsory insurance in the transport sector.

Law No.7703, date 11.5.1993 For social insurances in Republic of Albania.

Law No. 52|2014 for the insurance and re-insurance activity.

Rule No. 53/2009; For treating damages covered by the compulsory insurance contract in the transport contract.

Decree no. 295, date 15.09.1992 "For compulsory insurnace of holders of motor vehicles for responsibility to the thirds.

Decision no. 12 date 14,09.2007 of United Colleges of the Supreme Court.

Unifying decision no. 12 date 14.09.2007 of the United Colleges of the Supreme Court

Decision no. 173 date 31.03.2015 of the Civil College of the Supreme Court.

Decision no. 174 date 05.03 .2013 of the Supreme Court

Decision no. 199 date 15.05.2014 of the Civil College of Supreme Court.

Decision no. 4254 date 11.05.2018 of the Judicial District Court of Tirana.

Decision no. 236 date 06.03.2019 of the Appeal Court of Tirana.

Decision no.1 date 09.01.2008 of the United Colleges of the Supreme Court.

Decision no. 517 date 17.12.2015 of the Civil College of the Supreme Court.

Decision no. 10030/02.12.2009 of the Judicial District Court of Tirana.

Decision no.366, date 15.04.2011 of the Judicial District Court of Lushnjë

Decision no. 850 date 08.05.2006 of the First Instance Court of Vlorë

Decision no. 243 date 25.05.2010 of the Civil College of the Supreme Court.

Decision no. 1776 date 12.07.2017 of the Appeal Court of Tirana.

Decision no. 73 date 16.02 .2010 of the Civil College of the Supreme Court.

Decision no. 70/2010 of the Civil College of the Supreme Court.

Decision no. 714/2012 Appeal Court of Durrës

Decision no. 2614/2011 Appeal Court of Tirana

Decision no.13 date 27.01.2015 Judicial District Court of Fier

Decision, C.no.415/10 date 18.09.2013, Primary Court of Prishtine - branch of Podujeve

Decision C.no.199/11 date 04.12.2014, Primary Court in Prishtine

ECHR Case no. 57/1996/676/866 date 25 September 1997 